
ks. Ryszard Sztychmiler

Ius Matrimoniale

$31(2020) \mathrm{nr} 2$

DOI:10.21697/im.2020.31.2.04

Wydział Prawa i Administracji Uniwersytetu Warmińsko-Mazurskiego

ORCID 0000-0001-6441-3291

\section{Praca i honoraria adwokatów kościelnych}

Treść: Wstęp. 1. Rozwiązania i propozycje zgodnie akceptowane. 1.1. Znaczenie dobrej współpracy sędziów i adwokatów. 1.2. Opłaty sądowe. 1.3. Korzyść z udziału adwokata. 1.4. Zadania adwokata. 2. Oceny i propozycje nietrafne lub nieuzasadnione. 2.1. Opłaty sądowe. 2.2. Potrzeba adwokatów. 2.3. Poziom adwokatów. 2.4. Dokształcanie adwokatów i sędziów. 2.5. Czas pracy adwokata. 2.6. Wynagrodzenie. 3. Propozycje dyskusyjne. 3.1. Opłaty sądowe. 3.2. Problem zwalniania z opłat procesowych albo ich zmniejszania. 3.3. Charakter i warunki posługi adwokata. 3.4. Udział adwokata w przesłuchaniach 3.5. Porównywanie adwokatów kościelnych i świeckich. Wnioski.

\section{Wstęp}

W nawiązaniu do mojego artykułu opublikowanego w „Biuletynie Kanonistów Polskich” w 2019 r . oraz do wypowiedzi ks. dra Waldemara Gałązki z 2020 r. będącej jego uwagami do tegoż artykułu, koncentrującymi się na opłatach sądowych ${ }^{2}$, podejmuję próbę ustosunkowania się do jego propozycji. Najpierw wyróżnię uwagi - moim zdaniem - uzasadnione i te czasem doprecyzuję, następnie wskażę propozycje nietrafne, nieuzasadnione lub niezgodne ze stanem

\footnotetext{
1 R. Sztychmiler, Aspekty finansowe spraw o nieważność małżeństwa, Biuletyn Stowarzyszenia Kanonistów Polskich 29(2019) nr 32, s. 195-224.

2 W. GAŁĄzKA, Głos dotyczący opłat sądowych, Biuletyn Stowarzyszenia Kanonistów Polskich 30 (2020) nr 33, s. 53-70.
} 
faktycznym, wynikające być może tylko z pospiesznej redakcji, albo niepełnego rozeznania, uprzedzeń lub emocji, a na końcu zwrócę uwagę na jego propozycje dyskusyjne, które mogą przyczynić się do dalszego precyzowania norm i zasad. Jako że mam spojrzenie na ten problem $\mathrm{z}$ obydwu perspektyw, z jednej strony jako byłego sędziego i oficjała (18 lat), a z drugiej strony jako czynnego adwokata (15 lat), reprezentującego także innych adwokatów kościelnych ${ }^{3}$, ufam, że uwagi te powinny przyczynić się do bardziej obiektywnego kształtowania opinii o pracy adwokatów przy sądach kościelnych oraz kształtowania możliwości sprawiedliwego wynagradzania ich pracy ${ }^{4}$. Podobnie jak ks. Gałązka, także traktuję poniższe uwagi jako wkład do dyskusji nad tak ważnym problemem sądowym, jakim są warunki posługi adwokatów kościelnych ${ }^{5}$. Należy tu przypomnieć, że adwokaci pracują w określonych warunkach pracy sądów kościelnych, kształtowanych przez oficjałów i biskupów diecezjalnych. Zatem atmosfera pracy w tych sądach, także dopuszczane opłaty sądowe, wywierają duży wpływ na pracę adwokatów kościelnych.

\section{Rozwiązania i propozycje zgodnie akceptowane}

\subsection{Znaczenie dobrej współpracy sędziów i adwokatów}

„Wszyscy zajmujący się kwestią pomocy stronom w procesach kościelnych lub pracą sądów kościelnych zgodni są co do znaczenia dobrej współpracy sędziów i adwokatów kościelnych. A jest to kwestia ważna, gdyż rzutuje na opinię o Kościele” (W.G., s. 68). Zagadnieniu temu cały rozdział poświęcił w swoim bardzo dogłębnym studium

\footnotetext{
3 Autor był w latach 2007-2019 przewodniczącym Korpusu Adwokatów Kościelnych w Polsce, a od 2019 r. jest prezesem Krajowej Izby Adwokatów Kościelnych.

4 Szersze i obiektywniejsze spojrzenie na analizowane tu problemy zapewnia też wielość wykorzystanej przeze mnie literatury, uwzględnienie opinii innych autorów, podczas gdy W. Gałązka nie wykorzystał piśmiennictwa. Powołał się tylko na mój artykuł; por. TAmżE, s. 68. To spowodowało, że oparł się on tylko na własnym (choć bogatym) doświadczeniu sędziowskim i na ustnych relacjach innych.

5 W. GaŁĄzKa, Głos dotyczący opłat sądowych, dz. cyt., s. 68.
} 
ks. biskup Miziński ${ }^{6}$, a warunki dobrej współpracy opisałem w artykule „Potrzeba norm Konferencji Episkopatu Polski dotyczących adwokatów kościelnych"7 . Godna polecenia w tym temacie jest praca zbiorowa „Współpraca sądu ze stronami i adwokatami”.

\subsection{Opłaty sądowe}

Wielu zauważa, że tak w Stolicy Apostolskiej, jak i w kościołach lokalnych w Polsce istnieją poważne trudności w ułożeniu spraw finansowych w sądach kościelnych zgodnie z wytycznymi Ojca św. Franciszka. Uznaje się, że „nawet trybunały Stolicy Apostolskiej nie są w stanie spełnić pragnienia papieża Franciszka" ${ }^{\circ}$ w kwestii bezpłatności procesów. Poważne propozycje w tej sprawie zawarte są w publikacjach ks. biskupa Mizińskiego ${ }^{10}$, prof. Sztychmilera ${ }^{11}$, dr J. Krzywkowskiej ${ }^{12}$.

Można zgodzić się z opinią, że „opłata dla wszystkich spraw rozpatrywanych w danym sądzie kościelnym winna być jednakowa co

6 A.G. Miziński, Status prawny adwokata w Kościele łacińskim, Lublin 2011, s. 463-542.

7 R. Sztychmiler, Potrzeba norm Konferencji Episkopatu Polski dotyczacych adwokatów kościelnych, Studia Włocławskie, t. 21, Włocławek 2019, s. 435-448.

${ }^{8}$ R. SzTychmiler, J. Krzyw KOwsKa (red.), Współpraca sądów ze stronami i adwokatami, Olsztyn 2011.

9 W. GAŁĄzKA, Głos dotyczacy opłat sądowych, dz. cyt., s. 53; Franciscus PP., Litterae apostolicae motu proprio datae Mitis Iudex Dominus Iesus quibus canones Codicis Iuris Canonici de causis ad matrimonii nullitatem declarandam reformantur (15.08.2015), AAS 107 (2015), s. 958-970; tekst polski: FrANCISzEK, List apostolski motu proprio Mitis Iudex Dominus Iesus reformujący kanony Kodeksu Prawa Kanonicznego dotyczące spraw o orzeczenie nieważności małżeństwa (tekst łacińsko-polski), Wydawnictwo Diecezji Tarnowskiej Biblos, Tarnów 2015.

10 A. Miziński, Status prawny adwokata, dz. cyt., s. 224-226.

11 R. Sztychmiler, Posługa adwokata po „Mitis Iudex”, w: J. KrajCzyński (red.), Proces małżeński według motu proprio Mitis Iudex Dominus Iesus, Płock 2015, s. 127-142, Tenże, Potrzeba norm Konferencji Episkopatu, dz. cyt., s. 439-441; J. Krzyw Kowska, R. SzTychmiler, Adwokat w sprawach o nieważność małżeństwa. Rozwiązania ustawodawcze i ich stosowanie w sądach kościelnych (1983-2018), Olsztyn 2018, s. 62-69.

12 J. Krzyw KOwsKa, R. SzTychmiler, Adwokat w sprawach o nieważność małżenstwa, dz. cyt.; J. KRzYw KowsKA, Adwokat - realny pomocnik czy zbędny „dodatek”, Roczniki Nauk Prawnych KUL 2020 (w druku). 
do istoty" (W.G., s. 54). Jednak uzasadnione wydaje się pewne zróżnicowanie, zależne np. od liczby tytułów nieważności czy konieczności korzystania z pomocy zagranicznej, gdy strona lub świadkowie mieszkają poza Polską ${ }^{13}$. „Bardziej sprawiedliwa od jednakowej opłaty dla wszystkich jest stosowana przez niektóre sądy jej wysokość w zależności od zarobków strony (jedna miesięczna pensja)" (W.G., s. 54). Jest to propozycja rozsądna, lecz jej Autor niepotrzebnie boi się takiego rozwiązania. Sposoby weryfikowania oświadczeń stron o zarobkach w tej kwestii nie są bowiem zbyt trudne. Podtrzymuję opinię wyrażoną w artykule z 2019 r. (s. 206), iż miarodajną winna być opinia wyrobiona na podstawie okazania przez powoda, a tym bardziej przez proszącego o obniżenie kosztów, jego zeznania podatkowego za ostatni rok i ocenienia go w świetle opinii pozyskanej w tej sprawie bezpośrednio od proboszcza. Pewnym ułatwieniem pracy sądu byłoby ustalenie przez biskupa stawki np. o 50\% wyższej od dotychczasowej i powód, który nie chciałby ujawniać swoich zarobków, ponosiłby pełną opłatę, a kto chciałby jej obniżenia, wykazałby swoją niezamożność kopią zeznania podatkowego, którą sąd oceniłby w świetle opinii proboszcza. Za słuszne uważam też partycypowanie strony pozwanej w kosztach procesu, jeżeli składa ona skargę wzajemną (W.G., s. 55). Nie umniejszałoby to opłaty powoda, lecz wspomagałoby budżet sądu.

\subsection{Korzyść $\mathrm{z}$ udziału adwokata}

Nie tylko wtedy, gdy akta sprawy sugerują możliwość nieważności małżeństwa $z$ jeszcze innego tytułu, czyli innego niż od początku rozpatrywany, jest korzyść $z$ udziału adwokata, któremu łatwiej jest przekonać stronę niż sędziemu, i który nie musi zachowywać takiej bezstronności jak sędzia, co akceptuje także ks. Gałązka (s. 59), lecz w każdej sprawie, w której strona, nie znając zasad procesu kanonicznego, czuje się nieporadna i prosi adwokata o pomoc.

13 Takie zróżnicowanie, gdy strona procesowa mieszka poza Polską, stosuje Metropolitalny Sąd Archidiecezji Warmińskiej. Stawka wzrasta wtedy o 20\%. http:// archwarmia.pl/sad-biskupi (dostęp 19.01.2021). 


\subsection{Zadania adwokata}

Słusznie Autor omawianego artykułu przyznaje, że do zadań adwokata należy również „przedstawianie twierdzeń, zgłaszanie wniosków, a więc także żądania”, nie tylko obrona, lecz także stawianie wniosków i żądań; dlatego słusznie proponuje określenie jego funkcji mianem „posługa” czy „ministerium”, jak to jest w kan. $1481 \$ 3$ KPK (W.G., s. 60). Ale skoro przypomina tam, że obrona i żądania mają swoje granice, to należy dodać, że odnosi się to nie tylko do adwokata, lecz także sędziego. Gdy wykształcony adwokat, w interesie strony, domaga się zapisania ważnej w sprawie wypowiedzi strony czy świadka, sędzia nie powinien zabraniać mu postawienia takiego wniosku i grożenia wyłączeniem go z procesu. Celem procesu i zasadą naczelną powinno być zawsze dążenie do wykrycia i ustalenia prawdy. Słusznie podkreślił, że „żądając orzeczenia nieważności małżeństwa i broniąc swoich klientów adwokat ma również pomagać sędziom w dojściu do prawdy" (W.G., s. 60). Nie wiem, na jakiej podstawie Autor ten podejrzewa tam, że adwokat może dążyć do wygrania sprawy wbrew sumieniu. W swojej wieloletniej praktyce adwokackiej nigdy nie miałem takiej sytuacji. Gdy sprawa nie ma dużych szans powodzenia, zawsze odradzam jej wnoszenie do sądu. A gdy w sprawie niepewnej strona pomimo tego prosi o pomaganie jej, udzielam jej porad formalnych, pomagam napisać pismo przedstawiające jej argumenty, ale nie domagam się wtedy jednoznacznie potwierdzenia stanowiska tej strony. Przypominam też stronie, że ostateczne rozstrzygnięcie należy do sędziego ${ }^{14}$.

\section{Oceny i propozycje nietrafne lub nieuzasadnione}

\subsection{Opłaty sądowe}

Moim zdaniem nie można zgodzić się z opinią ks. Gałązki, że „nieuczciwa byłaby też opłata dla jednej strony większa, dla drugiej mniejsza" (s. 55). Innego bowiem nakładu pracy sądu wymaga rozpatrzenie sprawy wniesionej przez stronę, a innego dodanie potem

\footnotetext{
14 Por. J. Krzywkowska, R. Sztychmiler, Adwokat w sprawach o nieważność małżństwa, dz. cyt., s. 96-101.
} 
nowego żądania czy tytułu przez tę samą lub drugą stronę. Nie widzę podstawy nieuczciwości w sytuacji, gdzie strony zobowiązane zostaną do różnych opłat sądowych.

\subsection{Potrzeba adwokatów}

Choć W. Gałązka przyznaje: „W sądach kościelnych adwokaci są potrzebni. W sprawach karnych i spornych oprócz małżeńskich są niezbędni." (s. 58), to zaraz dodaje, że w moim artykule i w stanowisku Stolicy Apostolskiej rola adwokatów w procesach małżeńskich (przynajmniej w Polsce) jest przeakcentowana, że nie ma potrzeby istnienia wielu adwokatów, gdyż „uważna lektura akt przez sędziego i jego żądanie zgłoszenia przez stronę nowych dowodów, albo sugestia zgłoszenia dodatkowego tytułu nieważności małżeństwa” (s. 58) są wystarczającymi środkami dojścia do prawdy. Jego zdaniem „sędziowie nie są bezduszni, a zgodnie z kan. 1452 KPK mają też obowiązek z urzędu pomóc w doprowadzeniu do wyroku sprawiedliwego" (s. 58). To prawda, ale w ilu przypadkach sędziowie, obarczeni często wieloma sprawami, tak zagłębiają się w sprawę na etapie postępowania dowodowego? Na ogół studiowaniem sprawy, oceną dowodów, sędziowie zajmują się już po zamknięciu postępowania dowodowego. Tylko adwokat może oceniać dowody, ewentualnie sugerować zgłoszenie nowych, gdy zgłoszone wcześniej okazały się niewystarczające lub nieużyteczne. Tak może się zdarzyć, gdy świadkowie udzielili lakonicznych wypowiedzi (albo tylko tak zostały one zapisane) lub zasłonili się niepamięcią. Dlatego udział adwokata może mieć ogromne znaczenie.

Jakby tego nie rozumiejąc, W. Gałązka napisał: „Udział adwokata uważam, w zdecydowanej większości spraw, za mało, a nawet wcale nieprzydatny, niepotrzebnie obciążający strony finansowo. (...) Nie widzę jednak wyjścia z tej sytuacji, tym bardziej, że wskutek ponagleń myślącej zachodnimi realiami Sygnatury Apostolskiej, udział adwokatów kościelnych stał się już powszechny" (s. 59). Wyraził też opinię, że „w diecezji wystarczyłoby dwóch adwokatów, a nawet jeden. Bowiem (...) ich prawdziwa rola w procesach małżeńskich w Polsce jest bardzo mała, a niekiedy nawet żadna” (s. 67). Jego zdaniem tylko w niewielu sprawach jest potrzebny wysoki poziom obrony, a więc 
i udział adwokata (s. 59). Pozostaje mieć tylko nadzieję, że tak skrajnie nieobiektywna ocena potrzeby udziału adwokata w procesach kanonicznych jest głosem odosobnionym. W odpowiedzi wystarczyłoby przypomnieć treść kan. 1481-1482 i 1490. Ale skoro wyrażone zostały zastrzeżenia jak wyżej, warto przytoczyć najważniejsze w tej materii wyniki badań przedstawione w najnowszym opracowaniu monograficznym na temat adwokatów kościelnych, zwłaszcza w sprawach o nieważność małżeństwa ${ }^{15}$. Przytoczę tu tylko istotne w omawianej materii ustalenia ze wspomnianej monografii, oparte na pokaźnej literaturze na ten temat.

„Każda osoba, której przysługuje zdolność procesowa i jest stroną w sprawie, może działać w sądzie osobiście lub przez ustanowionego przez siebie pełnomocnika lub/i adwokata. (...) Działalność adwokatów w kościelnym wymiarze sprawiedliwości, a zwłaszcza w sprawach o orzeczenie nieważności małżeństwa, stanowi wyraz troski Kościoła o ochronę porządku prawnego obowiązującego w Kościele oraz przyczynia się do budowania Kościoła poprzez służbę dla dobra wiernych i zbawienia ich dusz. Jan Paweł II w przemówieniu do Roty Rzymskiej z 1989 r. podkreśla, że wymiar sprawiedliwości powinien zagwarantować stronom prawo do obrony i działać w «interesie ich prawa do obrony». Należy podkreślić, że prawo do obrony przysługuje stronie na każdym etapie procesu. (...) Na sądzie jednak ciąży obowiązek zagwarantowania małżonkom prawa do korzystania - zwłaszcza w sprawach skomplikowanych - z pomocy kompetentnych osób. To podmiotowe prawo stron procesowych jest równorzędne $\mathrm{z}$ zobowiązaniem biskupów diecezjalnych do stworzenia warunków koniecznych do istnienia i działania adwokatów przy sądach kościelnych. (...) Proces o nieważność małżeństwa jest specyficznym rodzajem duszpasterstwa, ponieważ dotyczy osób dotkniętych trudnymi problemami sumienia.

15 TAmże, s. 27-41; por. także: R. SzTyChmiler, Prawo do pomocy adwokata $w$ sądownictwie kościelnym, w: K. CIUćKOwsKa, J.J. SzczerbowsKi (red.), In varietate concordia. Księga jubileuszowa z okazji XXX-lecia pracy naukowej Profesora Bronisława Sitka, Warszawa 2019, s. 301-318; TENŻE, Znaczenie udziału adwokata $w$ kanonicznych procesach małżeńskich, w: R. SzTychmiler, J. Krzyw Kowska (red.), Problemy z sadowa ochrona praw człowieka, Olsztyn 2012, t. 1, s. 57-69; T. RozKrut, Adwokat i pełnomocnik procesowy w procesie kościelnym, Polonia Sacra 22/4 (2000), nr 7/51, s. 275-288. 
Znajdują się oni w skomplikowanej sytuacji, czasami bez własnej winy. Świadomość zaś w obszarze kanonicznego prawa procesowego jest ciągle słaba. Odnosi się to nie tylko do wiernych świeckich, ale czasem także i do duchownych. Wiele jest osób, nawet wśród katolików, które nie znają zasad prowadzenia spraw sądowych, nie mają wiedzy koniecznej chociażby w kwestii sporządzenia skargi powodowej. (...) Solidne wypełnianie przez adwokatów swoich obowiązków na poszczególnych etapach procesu jest wielką pomocą dla strony, która ma większe możliwości dobrego poznania i wykorzystania swoich uprawnień procesowych, bardziej przemyślanego działania i łatwiejszego udowodnienia swojego poglądu (...) Urząd adwokata służy także sprawniejszemu przebiegowi procesu, odkryciu i poznaniu prawdy obiektywnej w odniesieniu do konkretnych małżeństw zaskarżonych przed forum kościelnym oraz umacnianiu poczucia sprawiedliwości w Kościele. Nacisk adwokatów na wnikliwsze rozpatrywanie spraw przyczynia się m. in. do solidnego uzasadniania decyzji sędziowskich, a tym samym podnosi poziom sądownictwa kościelnego. (...) Potrzeba istnienia adwokatów w sprawach o nieważność małżeństwa jest duża. Wskazują na to ustawiczne monity ze strony Najwyższego Trybunału Sygnatury Apostolskiej do polskich trybunałów kościelnych, które spowodowały, że obecnie w prawie każdym sądzie ustanowiony został przynajmniej jeden adwokat kościelny. (...) praktyka uczy, że czasem i sędzia przekracza swoje kompetencje procesowe, przed czym strona czasem usiłuje się bronić. A przekroczenie kompetencji przez sędziego łatwiej zauważa adwokat niż sama strona i dlatego w takiej sytuacji stara się on $\mathrm{z}$ reguły pomagać stronie procesowej $\mathrm{w}$ upominaniu się o jej prawa. W związku z tym w niektórych sądach adwokaci traktowani są jako osoby potencjalnie wytykające błędy, a tym samym utrudniające pracę sądu. (...) Reasumując należy jednak uznać, iż udział adwokata w kanonicznym procesie o stwierdzenie nieważności małżeństwa jest bardzo potrzebny, przynoszący korzyści tak stronom procesowym, jak i sędziom"16.

16 J. Krzyw Kowska, R. SzTyChmiler, Adwokat w sprawach o nieważność matżeństwa, dz. cyt., s. 28, 33-41; por. Ioannes Paulus II, Allocutio ad Romanae Rotae auditores, officiales et advocatos coram admissos, 26.01.1989, AAS 81 (1989), s. 922-927. 
Zapewne lepiej będzie dla strony i dla sądu, gdy strona skorzysta z pomocy specjalisty z prawa kanonicznego, adwokata kościelnego, a nie będzie korzystała $\mathrm{z}$ nierzetelnych informacji zamieszczonych na stronach internetowych lub przekazywanych przez nieuprawnionych radców prawnych lub adwokatów ${ }^{17}$.

\subsection{Poziom adwokatów}

W. Gałązka posuwa się do stwierdzenia, że nie słyszał „o adwokacie kościelnym w Polsce, który by umiał głębiej wniknąć w doktrynę prawa, zrozumieć na przykład istotę wykluczenia zgody małżeńskiej, naturę rozeznania oceniającego praw i obowiązków małżeńskich (...). Widocznie miał on pecha i miał do czynienia tylko $\mathrm{z}$ adwokatami pełniącymi swoją funkcję jedynie teoretycznie, nie przykładającymi się solidną pracą do sprawy, bądź z tymi, którzy w internecie ogłaszają się jako specjaliści od rozwodów kościelnych, są może prawnikami, ale nie z zakresu prawa kanonicznego. Wygląda na to, że W. Gałązka nie czytał dotyczących spraw o nieważność małżeństwa prac choćby

Tekst polski: Jan PaWe€ II, Przemówienie do Trybunału Roty Rzymskiej, 26.01.1989, w: Jan Pawe€ II, Dzieła zebrane, t. 5, Kraków (Wydawnictwo M) 2007, s. 674-677; A. Stankiewicz, Geneza i ogólna charakterystyka instrukcji „Dignitas connubii”, w: T. Rozkrut (red.), Proces małżeński według Instrukcji „Dignitas Connubii”. Materiały z ogólnopolskiego spotkania pracowników sądownictwa kościelnego w Gródku nad Dunajcem w dniach 13-14 czerwca 2005 roku (II Ogólnopolskie Forum Sądowe), Tarnów 2006, s. 28; R. SzTychmiler, Adwokat w procesie o nieważność małżeństwa, w: T. Rozkrut (red.), Proces malżeński w świetle „Dignitas connubii” - pierwsze doświadczenia. Materialy z ogólnopolskiego spotkania pracowników sądownictwa kościelnego w Gródku nad Dunajcem w dniach 11-12 czerwca 2007 roku. III Ogólnopolskie Forum Sądowe, Tarnów 2008, s. 103-128; Tenże, Potrzeba udziału adwokata w procesie o nieważność małżeństwa, „Biuletyn Stowarzyszenia Kanonistów Polskich” 6 (1994) nr 1, s. 37-38. W Metropolitalnym Sądzie Archidiecezji Warmińskiej występuje obecnie 13 sędziów i 10 adwokatów.

$17 \mathrm{~J}$. KrzywKowsKa, Wypaczony obraz procesów o nieważność matżeństwa wyzwaniem dla sądownictwa kościelnego, w: J. KRZYNóweK, J. KRZYwKowsKa (red.), Ochrona małżeństwa i rodziny w Polsce. Zagadnienia prawne, Olsztyn 2015, s. 97-106. 
takich autorów, jak ks. bp prof. Artur Miziński ${ }^{18}$, ks. prof. Ryszard Sztychmiler ${ }^{19}$ czy dr Justyna Krzywkowska ${ }^{20}$.

18 A.G. Miziński, Adwokat gwarantem prawa do obrony w procesie kanonicznym, w: T. Rozkrut (red.), Urzędy sądowe - władza i służba. Materiały z ogólnopolskiego spotkania pracowników sądownictwa kościelnego w Gródku nad Dunajcem w dniach 11-12 października 2004 roku, Tarnów 2005, s. 35-64; TenżE, Instytucja obrońcy stałego w Kodeksie Prawa Kanonicznego $z 1983$ r., Roczniki Nauk Prawnych 14 (2004) nr 2; TenżE, Status prawny adwokata, dz. cyt.; Tenże, Weryfikacja racji ustanowienia urzędu obrońcy stałego w kontekście trudności i jego praktycznych zastosowań, Prawo - Administracja - Kościół 14 (2003) nr 3, s. 63-80.

19 R. Sztychmiler, Adwokat w procesie o nieważność małżéstwa, dz. cyt.; Tenże, Ochrona praw człowieka w normach kanonicznego procesu spornego, Olsztyn 2003, s. 186-193; TenżE, Odnowienie funkcji adwokata przy sądach kościelnych, Białostockie Studia Prawnicze 8 (2010), s. 44-58; Tenże, Posługa adwokata po „Mitis Iudex”, dz. cyt., s. 127-142; Tenże, Potrzeba udziału adwokata w procesie o nieważność matżeństwa, dz. cyt.; Tenże, Prawa stron procesowych $w$ kanonicznym procesie o nieważność małżeństwa, w: E. Szczot, S. BIAŁEK (red.), Zagadnienia kościelnego prawa majątkowego i procesowego, Lublin 2008, s. 101-116; TenżE, Prawo do obrony w procesie kanonicznym, w: J. Wroceński, J. KrajCZyńsKi (red.), Finis legis Christus. Księga Pamiątkowa dedykowana Księdzu Profesorowi Wojciechowi Góralskiemu z okazji siedemdziesiątej rocznicy urodzin, t. 1, Warszawa 2009, s. 791-807; TENżE, Sądownictwo kościelne w służbie praw człowieka, Olsztyn 2000; TenżE, Składki ubezpieczeniowe adwokatów kościelnych, w: P. SoвCzy , K. WARCHA£owski (red.), Finansowanie Kościołów i innych związków wyznaniowych, Warszawa 2013, s. 293-301; TenżE, Udział adwokata w przestuchaniach stron, w: J. Wroceński, H. Pietrzak, Ars boni et aequi. Księga pamiątkowa dedykowana Księdzu Profesorowi Remigiuszowi Sobańskiemu z okazji osiemdziesiątej rocznicy urodzin, Warszawa 2010, s. 543-553; Tenże, Udział adwokata w procesie o nieważność małżństwa po reformie procesu $z 2015$ roku, w: J. Krzywkowska, R. Sztychmiler (red.), Procedury w sprawach małżńskich i rodzinnych. Teoria i praktyka, Olsztyn 2016, s. 35-50; Tenże, Zadania adwokata związane $z$ udziałem biegłych $w$ procesie o nieważność małżeństwa, w: T. RozkRUT (red.), Zalety oraz wady kanonicznego procesu o stwierdzenie nieważności małżeństwa. V Ogólnopolskie Forum Sądowe, Tarnów 2012, s. 143-155; Tenże, Znaczenie udziału adwokata w kanonicznych procesach małżeńskich, dz. cyt., s. 57-69.

20 J. Krzywkowska, Adwokat kościelny dawniej i dziś, w: B. Sitek, C. Lazaro Guillamon, K. Naumowicz, K. Zaworska (red.), Interes prywatny a interes publiczny w prawie rzymskim, Olsztyn 2012; TENŻE, Adwokat kościelny a służba prawdzie, w: J. Zimny (red.), Autorytet: wyzwania - oczekiwania - zadania, Stalowa Wola 2016; TENŻE, Łączenie funkcji adwokata $z$ funkcja petnomocnika $w$ procesie 


\subsection{Dokształcanie adwokatów i sędziów}

W. Gałązka pyta, ilu adwokatów rzeczywiście pogłębia swoją wiedzę, czyta opracowania z dogmatyki materialnego prawa małżeńskiego. Pośrednio więc podważa takie zaangażowanie adwokatów. Odpowiadam więc, że adwokaci zrzeszeni w Krajowej Izbie Adwokatów Kościelnych (KIAK), a do 2019 r. w KAK - Korpus Adwokatów Kościelnych w Polsce, mają w swoim statucie zobowiązanie do pogłębiania wiedzy kanonistycznej i wiem, że czynią to. Czasem posyłam im odpowiednią bibliografię. Niektórzy uzyskują stopnie naukowe, np. doktoraty.

W. Gałązka napisał, że „ideałem byłoby, żeby adwokat miał taką samą wiedzę jak sędzia” (s. 67). Moim zdaniem sędzia powinien mieć większe wykształcenie i wiedzę niż adwokat. A czasem zdarza się, że jest odwrotnie. Adwokata ze słabymi kompetencjami sędzia może upomnieć lub usunąć z listy adwokackiej. Zaś adwokat nie ma takiej możliwości, gdy sędzia niekompetentnie prowadzi sprawę, gdy np. nie dopuszcza do realizacji uprawnień strony czy adwokata.

\subsection{Czas pracy adwokata}

Zdaniem W. Gałązki typowy adwokat kościelny w Polsce poświęca przeciętnej sprawie „kilka, najwyżej kilkanaście godzin” (s. 61). Wprawdzie przyznaje tam, że „bywa i więcej (zwłaszcza ostatnio), ale dość rzadko. Najczęściej redaguje skargę, nie zawsze jednak zapoznaje się z materiałem dowodowym podczas publikacji akt i, co za tym idzie, pisemnie ustosunkowuje się do ich treści, jeszcze rzadziej odpowiada na uwagi przedwyrokowe (wotum) obrońcy węzła małżeńskiego i wyjątkowo przygotowuje pismo apelacyjne" (s. 61).

Moim zdaniem jest to karykaturalny obraz pracy adwokatów. Jeśli rzeczywiście takich spotykał, to mu współczuję. Widzę pewne efekty pracy adwokatów, gdy zgłasza się do mnie strona prosząc

o nieważność małżeństwa, w: R. SzTychmiLer, J. KRZYw KowsKa (red.), Współpraca sądów ze stronami procesowymi i adwokatami, Olsztyn 2011, s. 135-142. 
o pomoc w procesie apelacyjnym. Widzę, że piszą odpowiedzi na uwagi obrońcy węzła małżeńskiego i głosy obrończe. A praca ze stroną w jednej sprawie od etapu przedprocesowego do jej zakończenia wymaga od kilkudziesięciu do kilkuset godzin pracy ${ }^{21}$. Moje doświadczenie wykazuje, że jednej sprawie poświęca się średnio 100-200 godzin pracy, co odpowiada prawie lub ponad jednomiesięcznemu wymiarowi pracy.

\subsection{Wynagrodzenie}

W. Gałązka postawił pytanie: „Jakie wynagrodzenia adwokatów należy uznać za sprawiedliwe i proporcjonalnie do ilości czasu poświęconego sprawie słuszne?” (s. 63). Dla uzasadnienia swojej opinii $\mathrm{w}$ tej kwestii podaje, że czas pracy adwokata w jednej sprawie to „najczęściej 5-10 godzin, rzadko więcej, a częściej mniej” (s. 64), że jego wynagrodzenie w wysokości 500 złotych (a nawet mniej) jest wystarczające, a przy tak małym nakładzie pracy domaganie się dla niego miesięcznego zarobku jest niewłaściwe, zwłaszcza w porównaniu do pracy oficjała, który „miesięcznie pracuje kilkadziesiąt godzin (...) pobiera w naszym sądzie najniższą pensję krajową" (s. 64). Dalej przytacza pozyskane informacje, że niektórzy adwokaci biorą „za napisanie skargi 300 złotych, a za udział w całym procesie $3000 \mathrm{zl}$ lub od 3 do 5 tysięcy złotych”. Dalej sugeruje, że „jeżeli wymieniony adwokat ma miesięcznie 5 spraw (w jednym czy kilku sądach), to zarabia miesięcznie 15000-20000 złotych. (...) Podtrzymuję stanowisko, że realna praca przeciętnego adwokata kościelnego w Polsce warta jest nie więcej jak kilkaset, a na pewno nie tysiąc złotych. (...) Proponowane 50-100\% przeciętnego miesięcznego wynagrodzenia

\footnotetext{
21 J. Krzyw Kowska, R. SzTychmiler, Adwokat w sprawach o nieważność małżeństwa, dz. cyt., s. 93-119; M. Greszata, Dylematy dotyczące udziału adwokata w procesie o nieważność małżeństwa, w: A. DzięGA, M. Greszata, P. Telusiewicz (red.), Kościelne prawo procesowe. Prawo rodzinne. Materiały i studia, t. 4, Lublin 2007, s. 215-228; A. Miziński, Status prawny adwokata w Kościele łacińskim, dz. cyt., s. $371-462$.
} 
krajowego adwokata uważam za zbyt wysokie, tym bardziej, że realna jego praca przeważnie jest niewielka. Przytaczana za bpem A. Mizińskim wysokość wynagrodzenia adwokatów w Italii w wysokości 150$250 \%$ miesięcznego wynagrodzenia sędziego w warunkach polskich jest nie do pomyślenia” (s. 65-66).

Podtrzymuję opinię z mojego poprzedniego artykułu (komentowanego przez ks. Gałązkę, s. 214), że w sytuacji, gdy tzw. adwokaci stali (kurialni) nie mogą pomóc stronie procesowej, która uzyskała od sądu przywilej bezpłatnej pomocy (DC, art. $112 \$ 2$ ), wezwany przez sąd do pomocy adwokat prywatny winien otrzymać od diecezji honorarium nie mniejsze niż 50\% minimalnego wynagrodzenia krajowego obowiązującego w dniu zlecenia prowadzenia sprawy (DC, art. $113 \$ 3)$.

Wierzę, że niektóre informacje podane przez dra Gałązkę są prawdziwe. Jednak niektóre są niewątpliwie fałszywe, podobnie jak wyprowadzane na ich podstawie wnioski. Podstawowym błędem, z którego wynikają następne, jest błędna ocena czasu pracy adwokata. Na podstawie własnego doświadczenia i rozmów z innymi legalnymi adwokatami stwierdzam, że na samo przygotowanie skargi powodowej (jedna lub kilka rozmów ze stroną, ewentualne ustalanie podstawy skargi i listy dowodów, rady dotyczące pozyskiwania dokumentacji, napisanie skargi i skonsultowanie jej ze stroną) potrzeba przynajmniej 6-10 godzin pracy, czyli tyle, ile wspomniany autor przewiduje na cała sprawę. A jeśli strona przedstawi wiele dokumentów i zaświadczeń (czasem też ręcznie pisanych relacji lekarskich), to potrzebne jest drugie tyle czasu. Sędziowie czasem nie doceniają, ile pracy zaoszczędzi im adwokat przez dobrą selekcję materiału załączanego do skargi, gdy doradzi włączenie tylko tych wiadomości i dokumentów, które będą miały znaczenie w danej sprawie. Widziałem skargę przygotowaną przez niefachowca, która obejmowała 80 stron.

Drugim zadaniem jest przekazanie sędziemu szczegółowych pytań dla stron, jeśli on sam nie uwzględnił wyjaśnienia kwestii ważnych w danej sprawie. Adwokat wie, co z historii małżeństwa, opowiedzianej przez stronę, ma duże znaczenie dla procesu, a więc o co strony winny być zapytane, aby mogły wypowiedzieć się w tych 
ważnych kwestiach. Aby podczas przesłuchań nie przeoczono tych kwestii, adwokat powinien mieć możliwość zapoznania się z pytaniami przygotowanymi przez sędziego i/lub obrońcę węzła małżeńskiego, aby w razie potrzeby dodać swoje pytania, umożliwiające stronom wypowiedzenie się w konkretnych i ważnych kwestiach. Dość często pytania przygotowywane w sądach, tak przez sędziów, jak i przez obrońców węzła małżeńskiego, są dość podobne, takie same lub podobne $\mathrm{w}$ wielu sprawach, nie uwzględniające sytuacji szczególnych z historii danego małżeństwa. Czasem wynikać to może ze zbyt małej obsady kadrowej sądów kościelnych i wynikającej stąd niemożliwości wnikania w historię małżeństwa, zawartą zwłaszcza w skardze powodowej i w odpowiedzi na nią. Brak ten może doskonale naprawić adwokat poprzez dołączenie pytań dopasowanych do wzmiankowanych $\mathrm{w}$ aktach i relacjonowanych w rozmowach $\mathrm{z}$ nim faktów, które mają istotne znaczenie dla dotarcia do prawdziwego obrazu zawieranego małżeństwa, a w konsekwencji do sprawiedliwego rozstrzygnięcia. Sędziowie nie powinni być o to zazdrośni, gdyż wspólnym interesem ich, obrońców węzła oraz adwokatów, jako osób znających prawo i uczciwych, a więc wspólnym interesem Kościoła, jest dotarcie do prawdy i wydanie sprawiedliwego wyroku. $\mathrm{Na}$ zapoznanie się z pytaniami sądu i przygotowanie dodatkowych pytań też trzeba kilka (4-6) godzin.

Jeśli strona prosi o udział adwokata w przesłuchaniach stron, to na to także trzeba liczyć ok. 5-6 godzin, a z dojazdami, nawet miejscowymi, dodatkowo 2-3 godz. Po tych przesłuchaniach stron znów trzeba przeczytać skargę i zeznania, zrobić z nich wypisy, aby zweryfikować listę dowodów i przygotować szczegółowe kwestie, o co winni zostać zapytani świadkowie. Na to też trzeba ok. 8-10 godzin. Gdy strona prosi także o udział adwokata w przesłuchaniach świadków, to na to także trzeba liczyć średnio ok. 20 godzin, a następnie podobną ilość czasu na spokojne sczytanie zapisanych zeznań i zrobienie z nich wypisów (gdyż sądy na ogół nie dają w tym czasie, a nawet i później) kopii lub elektronicznych zapisów zeznań (co znacznie ułatwiłoby pracę i skróciło jej czas). Na zapoznanie się z opinią biegłego, który w większości spraw występuje, oraz oceną jej użyteczności, adwokat 
też potrzebuje ok. 4 godzin. W sytuacji wcześniejszego czytania akt adwokat mniej czasu potrzebuje na całościowe spojrzenie na sprawę podczas publikacji akt i na ocenę wystarczalności materiału dowodowego. Dodatkowo należy zapoznać się z notatkami strony z czytania akt, gdyż ona może znaleźć nieprawdziwe zeznania lub oświadczenia, których nie mógł odkryć adwokat, nie znając tak dokładnie faktów jak strona. Można przyjąć, że wtedy potrzebować on może na to łącznie ok. 12-16 godzin. Jeśli trzeba wnioskować o dopuszczenie nowych dowodów i zostaną one dopuszczone, to ich przeprowadzenie i wypisanie zebranych argumentów też może zająć 8-12 godzin. Czasami strona może być nawet przesadnie dokładna czy skrupulancka i po każdym etapie procesu może wymagać po 1-2 godz. wyjaśnień. Najbardziej pracochłonnym i czasochłonnym zadaniem adwokata jest przygotowanie odpowiedzi na uwagi obrońcy węzła oraz sporządzenie głosu obrończego. To zajmuje na ogół 20-40 godzin pracy, a jeśli dla lepszego uzasadnienia wniosków trzeba szukać dodatkowych źródeł i literatury, to może być dodatkowych 20 godzin. Razem daje to ok. 110 godzin pracy adwokata w sprawie mało skomplikowanej, ok. 160 godzin przy średnio skomplikowanej, a ok. 200 godzin w sprawie wymagającej najwięcej pracy. Nie liczę tutaj czasu na napisanie uzasadnienia ewentualnej apelacji. Nie jest więc przesadne twierdzenie, że adwokat powinien za jedną sprawę otrzymywać równowartość 1-miesięcznego wynagrodzenia, a przynajmniej połowę. A jeśli porada u kanonisty kosztuje 150-200 zl, to też nie jest to zbyt wysoka opłata. Lekarz prywatnie za 15-minutową wizytę bierze tyle samo lub większe pieniądze. Dziś najbardziej niewykwalifikowany pracownik zarabia ponad 2000 zł miesięcznie, a godzina jego pracy nie może być opłacana mniej niż ok. 20 zł. Jeżeli strony nie stać na poradę adwokata kościelnego, wówczas ma możliwość skorzystania z bezpłatnej poradni sądowej czy rozmowy z pracownikiem sądu kościelnego ${ }^{22}$.

Komentarza wymaga też zazdrosny zapis dra Gałązki, że ileż to może zarabiać adwokat, jeśli weźmie 5-10 spraw miesięcznie, za każdą choćby po 3000 zł (a nie jak on proponuje i niektórzy biskupi ustalili,

22 Por. R. Sztychmiler, Potrzeba norm Konferencji Episkopatu, dz. cyt., s. 439-441. 
po 500 zł). Wzbudzający zazdrość błąd polega na możliwości przyjęcia takiej ilości spraw. Jest niemożliwe, aby jeden adwokat potrafił opiekować się 60-120 sprawami w ciągu roku. Adwokat może mieć 10 spraw jednocześnie, ale przyjmowanych w różnych miesiącach w ciągu całego roku. Sprawy trwają na ogół około roku. Wtedy prowadząc 10 spraw przez rok, ma wynagrodzenie z jednej na miesiąc.

Ale jest też pozytywny akcent. Cieszę się, że na końcu nietrafnych wywodów W. Gałązka zaakceptował propozycję pilnego ujednolicenia, czy przyjęcia jednolitych reguł ustalania honorariów adwokackich w Polsce. Dodam, że powinno to dotyczyć tak adwokatów umownych, jak i stałych (kurialnych), gdyż oni często także nie otrzymują godziwego wynagrodzenia.

\section{Propozycje dyskusyjne}

\subsection{Opłaty sądowe}

Podtrzymuję potrzebę rozsądnego uregulowania kosztów sądowych we wszystkich sądach kościelnych w Polsce, podobnie jak w innych krajach. Dlatego nie zgadzam się z opinią W. Gałązki: „Ustalenie jednakowych kosztów procesu dla całego kraju, a nawet metropolii uważam za nierealne" (s. 53). Tym bardziej, że na s. 65 tenże Autor pisze: „potrzeba uregulowania opłat dla adwokatów w skali krajowej jest niezbędna i pilna”. Rozwiązania ogólne dla całego kraju byłyby - w moim przekonaniu - bardzo pożyteczne i potrzebne. Można tu odnieść się do unormowań w tym zakresie w innych krajach, np. do regulacji we Włoszech ${ }^{23}$. Opłaty za procesy i pomoc adwokatów określane na zachodzie Europy w euro mogą być odpowiednie w Polsce w takiej samej kwocie, ale w polskich złotych. Proporcje między zarobkami stron oraz opłatami sądowymi i adwokackimi byłyby takie same.

\footnotetext{
23 J. Krzyw Kowska, R. Sztychmiler, Adwokat w sprawach o nieważność małżeństwa. Rozwiązania ustawodawcze i ich stosowanie w sądach kościelnych (1983-2018), dz. cyt., s. 68 .
} 
Ks. Gałązka napisał: „Nie uważam za właściwą, rzadko spotykaną praktykę niektórych sądów uzależniającą wysokość opłaty procesowej od ilości tytułów nieważności małżeństwa” (s. 55). Osobiście uważam tę praktykę za usprawiedliwioną. Rozpatrywanie kilku ewentualnych tytułów nieważności w jednej sprawie jest bardziej ekonomiczne dla strony niż rozpatrywanie ich w odrębnych procesach. Sąd i adwokat mają za to więcej pracy w tej sprawie. Należy im się dodatek za większy wymiar pracy. Ale kwestę tę należy pozostawić oficjałom i biskupom moderatorom.

Ważny problem postawiony też został w zdaniu: „Ile w porównaniu z takim adwokatem winien zarabiać sędzia kościelny?” (W.G., s. 57). Oczywiście powinien też otrzymywać godne wynagrodzenie. Ale nie wolno wprost wzajemnie uzależniać wynagrodzenia adwokata i sędziego. Adwokat nie jest konieczny, a jeśli strona chce mieć komfort w procesie i chce na podstawie cywilnej umowy zapłacić za tę pomoc, nie wolno jej bronić. Jeśli zechce skorzystać z bezpłatnego dla niej adwokata kurialnego (stałego), też nie wolno jej bronić. Natomiast prowadzenie procesu może być dla strony konieczne, aby wyjaśnić swoją trudną sytuację w Kościele. Dlatego opłaty sądowe nie powinny być zbyt wysokie. Natomiast rzeczą biskupa moderatora jest ustalenie, czy pracownicy sądu opłacani będą tylko z opłat sądowych, czy także z funduszy diecezjalnych, na które składają się wierni diecezji.

\subsection{Problem zwalniania $z$ opłat procesowych albo ich zmniejszania}

Choć dr Gałązka zgadza się z moją propozycją, aby od strony proszącej o zwolnienie z kosztów żądać dokumentu PIT oraz opinii proboszcza (s. 56), to dalej pisze: „Doświadczenie pokazało, że żądanie przedłożenia zaświadczenia od proboszcza o trudnych warunkach materialnych przeważnie jest mało warte. Proboszcz świadomy, że strona mieszka w jego parafii woli nie mieć z nią zatargu i przeważnie popiera prośbę; rzadziej daje pismo enigmatyczne, a jeszcze rzadziej opinię negatywną. Lepiej, jeżeli sam sąd zwróci się do proboszcza zastrzegając, że jego opinia pozostanie tajemnicą, ale to też rzadko pomaga. Proboszcz obawia się, że strona dowie się o jego opinii. Jeżeli 
da się przekonać i przysyła opinię niekorzystną dla petenta, trzeba szukać nie wynikającego z pisma proboszcza uzasadnienia odmowy zwolnienia z opłaty" (s. 57). Zgadzam się, że nie jest to zadanie łatwe, ale nie jest też bardzo trudne. Warto ten trud podjąć, aby zachować większą sprawiedliwość wobec stron, aby nie wymagać tyle samo od zamożnych i ubogich. Adwokaci nie stawiają w tej kwestii wymagań, a jedynie mogą prosić w imieniu stron.

\subsection{Charakter i warunki posługi adwokata}

Dr Gałązka postawił pytanie: „przed kim stronę ma bronić adwokat?” Oczywiście, przed roszczeniami drugiej strony procesowej, przed jej niesprawiedliwymi żądaniami, niezgodnymi z prawdą zarzutami itp. (...) sformułowania nasuwają wniosek, że adwokat ma bronić stronę ... przed trybunałem. Trochę naciąganym (chyba jednak nie przewrotnym) tokiem myślenia można uznać, iż pierwszym adresatem tej obrony, a może nawet głównym przeciwnikiem adwokata jest sędzia (s. 60). Jest to wniosek bardzo naciągany i nieuprawniony. Zadaniem adwokata jest obrona strony przed fałszem, przed fałszywą oceną jej sytuacji w czasie zawierania małżeństwa. Adwokat, podobnie jak sędzia, szuka prawdy o danym małżeństwie. W razie potrzeby będzie wspierał stronę przeciw nieprawdziwym oskarżeniom przez drugą stronę lub jej świadków, a gdy sytuacja będzie tego wymagała, także podważać może opinię biegłego i żądać nowej opinii, a także wnioskować o odpowiednie, zgodne z prawem, decyzje sędziego. Ten nie powinien go wtedy traktować jak wroga, lecz jako współpracownika w ustalaniu prawdy w przedmiocie sporu.

Słusznie W. Gałązka zauważył „obawę, że opłacanie adwokata przez pośrednictwo sądu może być uzależnianiem go od oficjała” (s. 60). Jest to obawa czasem uzasadniona, zwłaszcza gdyby oficjał lub inny sędzia usiłował ograniczać aktywność adwokata, np. nie zezwalać na korygowanie podczas przesłuchania zapisów zeznań. Dlatego lepiej jest, jeśli adwokat otrzymuje wynagrodzenie bezpośrednio od strony, a adwokat stały od kurii, a nie od sądu. Znam przypadki, gdy strona była ograniczana w swoich prawach, gdyż pracownik tego sądu 
był jednocześnie adwokatem czy doradcą strony przeciwnej. Posyłano wtedy pisma na nieaktualny adres strony, a gdy potem upominała się o przywrócenie terminu na złożenie swojego wniosku, nie było to przyjmowane. Dlatego nie powinno być tak (co jeszcze się zdarza), aby pracownik sądu (zwłaszcza sędzia) był jednocześnie adwokatem czy nieformalnym obrońcą, bo może wtedy działać na korzyść drugiej strony. Dobrze, że dalej tenże Autor przyznał, iż „Adwokat może, a nawet powinien zauważyć błąd popełniony przez sędziego, czy brak poprawności jego rozumowania" (s. 61).

Dobrze, iż W. Gałązka zauważył, że „ostatnio trochę częściej adwokaci zapoznają się z aktami sprawy przed ich publikacją" (s. 62), że dbają o ukierunkowanie dalszego biegu sprawy. Adwokat powinien wyciągać wnioski z przebiegu procesu. Nie powinien oczywiście przekazywać stronom (przed publikacją) treści zeznań, ale może powiadomić stronę, że zgłoszeni świadkowie nie powiedzieli nic istotnego w sprawie, zasłaniając się niepamięcią lub wtrącając niepotrzebne słowa, np. „wydaje mi się”, „jestem przekonana o ...”, podczas gdy byli świadkami danego wydarzenia czy wypowiedzi; a przez to osłabiają lub podważają swoje stwierdzenia. Wtedy adwokat powinien zapytać, czy strona ma innych świadków, którzy więcej pamiętają i mogliby więcej powiedzieć. Aby umniejszyć niebezpieczeństwo naruszenia równości stron w procesie, każda ze stron winna mieć możliwość powołania adwokata, czy to z listy adwokatów płatnych, czy z listy adwokatów opłacanych przez diecezję (stałych).

\subsection{Udział adwokata w przesłuchaniach}

Przykro mi, że doświadczenia ks. oficjała Gałązki z niektórymi adwokatami były mało satysfakcjonujące. Sam przyznał, że chyba tylko jeden raz spotkał się $\mathrm{z}$ adwokatem podczas przesłuchania strony procesowej, a ma „podejrzenie pouczania przez adwokatów stron procesowych co mają mówić w zeznaniach” (s. 62-63). Nie mogę w 100\% ręczyć za wszystkich adwokatów, ale jestem przekonany, że mogę ręczyć za należących do Krajowej Izby Adwokatów Kościelnych, w której stawia się wyższe wymagania niż tylko kodeksowe. A wiem, 
że niektórzy adwokaci, nawet zatwierdzeni, pobierają znacznie wyższe honoraria niż przeciętnie i nie uczestniczą w spotkaniach szkoleniowych i formacyjnych adwokatów kościelnych. Uważam, że biskupi zatwierdzając adwokatów mogliby się kierować tym, czy dana osoba jest „wolnym strzelcem”, czy należy do Izby Adwokatów Kościelnych, która dba także o ich formację, stawia wyższe wymagania i ma możliwość pewnej kontroli ${ }^{24}$. A jeśli ktoś nie chce poddać się takim wymaganiom, to też o czymś świadczy. Szkoda, że Konferencja Episkopatu Polski i Rada Prawna KEP działają tak ociężale, że przez ponad 10 lat nie są w stanie uregulować statusu adwokatów kościelnych w Polsce ${ }^{25}$.

Tak jak sędziemu okazuje się zaufanie, że będzie rozsądzał zgodnie $\mathrm{z}$ prawidłowym sumieniem, tak też należy okazywać zaufanie adwokatowi. A jeśli któremuś wykaże się nadużycie zaufania, można go wykluczyć. Przecież adwokaci kościelni kończą studia prawa kanonicznego, składają wyznanie wiary i zapewne są odpowiedzialni przed Bogiem i przed ludźmi za to, co robią. Zatwierdzają ich biskupi, którzy (na ogół przez oficjałów) mogą sprawdzić ich wiedzę i kwalifikacje moralne.

Wprawdzie Autor przyznaje, że udział adwokata podczas przesłuchania może być przydatny, ale potrzebę tę bezzasadnie ogranicza tylko do spraw skomplikowanych. Przyznaje choć tyle, że adwokat może w czasie przesłuchania podsunąć sędziemu dodatkowe pytania dla wyjaśnienia sprawy (s. 62). A przecież tylko wyjątkowo od razu widać, że sprawa jest oczywista i łatwa. Najczęściej są to sprawy trudne, a nigdy nie wiadomo, czy strony i świadkowie podczas przesłuchania przypomną sobie najważniejsze fakty, czy o nich powiedzą i czy sędzia lub notariusz potrafi wyłowić najważniejsze stwierdzenia i wiernie je zaprotokołować. Tych okoliczności nie sposób przewidzieć. Najlepiej, gdyby adwokat był przy każdym przesłuchaniu i pomagał sędziemu wiernie zapisać zeznania. Ale gdy stron nie stać na adwokata lub

24 Por. A. Mızıński, Status prawny adwokata w Kościele łacińskim, dz. cyt., s. $562-574$.

25 Por. R. SzTychmiler, Udział adwokata w przesłuchaniach stron, dz. cyt.; Tenże, Potrzeba norm Konferencji Episkopatu, dz. cyt., s. 429-433. 
sędzia nie dopuszcza go do głosu, większość przesłuchań odbywa się bez adwokata.

Znów wyrażam ubolewanie z powodu, pechowego moim zdaniem, niespotkania przez ks. Gałązkę „adwokatów przejawiających wiedzę kanonistyczną choćby trochę większą od minimalnej" (s. 62). Przez wiele lat adwokatów w diecezji sandomierskiej aprobował ówczesny Biskup Sandomierski, ks. prof. Andrzej Dzięga, który będąc jednocześnie profesorem KUL, miał wyjątkowe możliwości zebrania opinii (naukowej i osobowościowej) o kandydatach do funkcji adwokata. Mam prawo przypuszczać, że dopuszczał tych, którzy byli najlepszymi studentami. Szkoda, że nie spotykał adwokatów mających stopnie doktorskie czy tytuły profesorskie, a przypuszczam, że także adwokatów podnoszących swoje kwalifikacje, dawniej w Korpusie Adwokatów Kościelnych w Polsce, a obecnie w Krajowej Izbie Adwokatów Kościelnych. Ale przyznaję, że adwokatów, podobnie jak i sędziów, można różnie oceniać.

\subsection{Porównywanie adwokatów kościelnych i świeckich}

Mój szanowny Dyskutant napisał, że porównywanie wynagrodzenia adwokata kościelnego $\mathrm{z}$ adwokatem świeckim jest nieadekwatne, gdyż adwokaci świeccy „muszą przeznaczyć na sprawę dużo więcej czasu niż czynią to adwokaci kościelni” (s. 66). Uważam tę wypowiedź za dyskusyjną. Czasem może tak być. Ale wydaje się, że nakład pracy adwokata w sprawie zależy od kilku czynników: ilości dokumentów do analizy, doświadczenia adwokata, posiadania współpracowników czy personelu pomocniczego, a także solidności adwokata. Niektóre z tych czynników tak samo wpływają na pracę adwokata, tak w sądzie świeckim, jak i kościelnym. Ten argument przemawia za tym, że zasady wynagradzania obydwu grup adwokatów powinny być podobne. Różnice mogą wynikać z ilości dokumentów do analizy, ilości komentarzy do danej kwestii, a także z utrzymywania kancelarii, 
łącznie z opłacaniem podatków i składek ubezpieczeniowych ${ }^{26}$. Ilość pracowników kancelarii adwokackiej z jednej strony obciąża adwokata wypłacaniem pensji i ponoszeniem innych opłat, a $\mathrm{z}$ drugiej strony pozwala mu przerobić większą ilość spraw.

\section{Wnioski}

Jestem przekonany, że 33 lata mojej praktyki sądowej (jako sędzia, wiceoficjał, oficjał, adwokat) upoważnia mnie do wyrażenia powyżej swojego stanowiska i opinii w wielu kwestiach związanych z funkcjonowaniem sądów i adwokatów kościelnych w Polsce. Ufając, że i ta dyskusja ubogaci myślenie osób w niej (czynnie czy biernie) uczestniczących, formułuję swoje analizy, przemyślenia i wnioski.

Praca adwokatów kościelnych zależy od nich samych, ale także od określonych warunków pracy w sądach kościelnych, kształtowanych przez biskupów diecezjalnych, oficjałów i wszystkich pracowników sądowych. W analizie niektórych aspektów pracy i wynagradzania adwokatów kościelnych wyróżniłem kwestie, co do których rozwiązania i propozycje są przez autorów zgodnie akceptowane, następnie propozycje nieuzasadnione lub niezgodne ze stanem faktycznym, a na końcu zwróciłem uwagę na propozycje dyskusyjne.

W pierwszej części, wśród kwestii podobnie ocenianych przez obydwu autorów, poruszyłem kwestie: znaczenia dobrej współpracy sędziów i adwokatów, opłat sądowych, korzyści z udziału adwokata w procesie i zadań adwokata. W drugiej części wobec niektórych ocen nietrafnych i propozycji nieuzasadnionych dra Gałązki przedstawiłem swoje odrębne opinie w różnych aspektach dotyczących opłat sądowych, potrzeby adwokatów, poziomu ich pracy, dokształcania adwokatów i sędziów, czasu pracy adwokata i jego wynagrodzenia. W części trzeciej zaprezentowałem niektóre kwestie otwarte, które powinny być dopracowane w dalszych dyskusjach. Należą do nich niektóre aspekty opłat sądowych, zwalniania z tych opłat albo ich

26 Por. R. Sztychmiler, Składki ubezpieczeniowe adwokatów kościelnych, dz. cyt., s. 295-301. 
zmniejszania, charakteru i warunków posługi adwokata, udziału adwokata w przesłuchaniach oraz porównywania pracy adwokatów kościelnych i świeckich.

Z konkretnych wniosków szczególnie warto podkreślić niektóre z nich. Uzasadnione wydaje się pewne zróżnicowanie opłat za procesy kanoniczne, zależne np. od ilości tytułów nieważności, konieczności korzystania z pomocy zagranicznej, od zarobków strony. Do zadań adwokata należy obrona stanowiska reprezentowanej strony, przez przedstawianie twierdzeń, zgłaszanie wniosków i żądań, zawsze w granicach prawdy i prawa. W sądach kościelnych adwokaci są potrzebni, ich udział w procesie może mieć ogromne znaczenie. Działalność adwokatów w kościelnym wymiarze sprawiedliwości, a zwłaszcza w sprawach o orzeczenie nieważności małżeństwa, stanowi wyraz troski Kościoła o ochronę porządku prawnego obowiązującego w Kościele oraz przyczynia się do budowania Kościoła poprzez służbę dla dobra wiernych i zbawienia ich dusz. Udział adwokata w kanonicznym procesie o stwierdzenie nieważności małżeństwa jest bardzo potrzebny, przynoszący korzyści tak stronom procesowym, jak i sędziom. Solidne wypełnianie przez adwokatów swoich obowiązków na poszczególnych etapach procesu jest wielką pomocą dla strony, która ma wtedy większe możliwości. Urząd adwokata służy także sprawniejszemu przebiegowi procesu, odkryciu i poznaniu prawdy obiektywnej w odniesieniu do konkretnych małżeństw zaskarżonych na forum kościelnym oraz umacnianiu poczucia sprawiedliwości w Kościele. Adwokaci zrzeszeni w Krajowej Izbie Adwokatów Kościelnych (KIAK, a do 2019 r. KAK - Korpus Adwokatów Kościelnych w Polsce), mają w swoim statucie zobowiązanie do pogłębiania wiedzy kanonistycznej i czynią to. Podstawowym błędem niektórych autorów, z którego wynikają następne, jest błędna ocena czasu pracy adwokata. Wykazałem, że w sprawie mało skomplikowanej adwokat na pomoc stronie w całej sprawie potrzebuje ok. 110 godzin pracy, w sprawie średnio skomplikowanej potrzebuje ok. 160 godzin, a w sprawie wymagającej najwięcej pracy - ok. 200 godzin pracy, co odpowiada ok. jednomiesięcznemu wymiarowi pracy. Uzasadnione wynagrodzenie winno więc oscylować około równowartości jednomiesięcznego 
wynagrodzenia. Adwokat prywatny wezwany przez sąd do pomocy stronie ubogiej winien otrzymać od diecezji honorarium nie mniejsze niż 50\% minimalnego wynagrodzenia krajowego. Opłaty za procesy i pomoc adwokatów określane na zachodzie Europy w euro mogą być odpowiednie w Polsce w takiej samej ilości w polskich złotych.

Z wniosków szczególnie otwartych na dalszą dyskusję wymieniam: możliwość uzależniania wysokości opłaty procesowej od ilości tytułów nieważności małżeństwa, poziom godnego wynagrodzenia sędziów i adwokatów, konieczność zapewnienia każdej stronie procesowej możliwości skorzystania $\mathrm{z}$ bezpłatnej lub płatnej pomocy adwokata, możliwość zwalniania $\mathrm{z}$ opłat procesowych albo ich zmniejszania. Zadaniem adwokata jest obrona strony przed fałszem, przed fałszywą oceną jej sytuacji. Adwokat, podobnie jak sędzia, szuka prawdy o danym małżeństwie. $\mathrm{W}$ razie potrzeby będzie wspierał stronę przeciw nieprawdziwym oskarżeniom przez drugą stronę lub jej świadków, a gdy sytuacja będzie tego wymagała, także podważać może opinię biegłego. Adwokaci należący do Krajowej Izby Adwokatów Kościelnych spełniają wyższe wymagania niż tylko kodeksowe. Dlatego należy okazywać im większe zaufanie. Adwokatom należy okazywać podobne zaufanie jak sędziom. Wykształcenie, wymiar i jakość pracy adwokatów w sądach kościelnych i świeckich, a także ich wynagrodzenie powinny być porównywalne.

\section{Work and fees of ecclesiastical advocates}

\section{Summary}

The work of ecclesiastical advocates depends on themselves, but also on certain working conditions in the ecclesiastical courts, shaped by diocesan bishops, judical vicars and all court staff. In the analysis of certain aspects of the work and remuneration of ecclesiastical advocates, I have distinguished issues on which solutions and proposals are unanimously accepted by the authors, then proposals that are unjustified or inconsistent with the facts, and finally I have drawn attention to debatable proposals.

In the first part of the article, among the issues similarly assessed by both authors, I addressed the following issues: the importance of good 
cooperation between judges and advocates, court fees, the benefits of advocate's participation in proceedings and advocate's tasks. In the second part, in the face of some of Dr Gałązka's misjudgements and unjustified proposals, I presented my separate opinions on various aspects concerning court fees, the need for advocates, the level of their work, further training of advocates and judges, advocate's working time and their remuneration. In the third part, I presented some issues that should be elaborated upon in further discussions. These include, inter alia, certain aspects of court fees, their exemption or reduction, the nature and conditions of a advocate's service and his/her participation in interrogations.

Słowa kluczowe: adwokat, prawo kanoniczne, proces kanoniczny, adwokat kościelny, nieważność małżeństwa

Keywords: advocate, canon law, canonical trial, ecclesiastical advocate, marriage nullity

\section{Nota o autorze}

Ks. Ryszard Sztychmiler - profesor zwyczajny prawa kanonicznego, kierownik Katedry Prawa Kanonicznego i Wyznaniowego Wydziału Prawa i Administracji Uniwersytetu Warmińsko-Mazurskiego w Olsztynie, adwokat przy Metropolitalnym Sądzie Archidiecezji Warmińskiej. Członek Polskiego Towarzystwa Prawa Wyznaniowego, prezes Krajowej Izby Adwokatów Kościelnych. 